\title{
The Use of Stand-downs in New Zealand Schools: What are the Issues?
}

\author{
Carolyn White and Alison Kearney
}

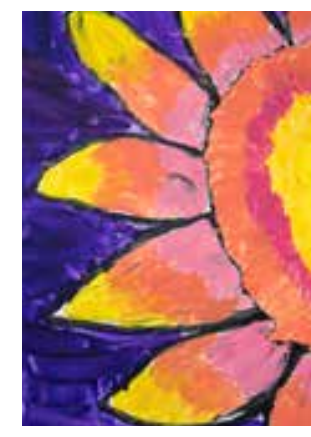

\begin{abstract}
In 2013, schools in New Zealand stood-down nearly 12,000 students as a result of behavioural difficulties. Research indicates that rather than improving behaviour, stand-downs can reinforce inappropriate behaviour and potentially put students at-risk. This paper overviews the use of stand-downs in New Zealand schools, discussing the nature and extent of their use. Using examples from a small case study based around two secondary school students who had recently been stood-down, the potential adverse effects and impacts of school stand-down are discussed, and arguments put forward for finding alternatives to the practice.
\end{abstract}

Keywords: Behaviour, discipline, exclusion, standdown

\section{Research Paper \\ INTRODUCTION}

As part of a disciplinary process, schools within New Zealand are able to stand students down for a period of up to five days, for a maximum of ten days per school year (Ministry of Education, 2009). Students can be stood-down for reasons of gross misconduct or continual disobedience if this behaviour is a harmful or dangerous example to other students or if, because of their behaviour, it is likely that the student or other students at the school will be seriously harmed if the student is not stood-down.

Based on two small case studies around students who had been stood-down from school, this paper argues for a reconsideration of the use of school standdowns based on research showing the far-reaching detrimental effects that excluding students from school can bring, the lack of any empirical data to indicate its effectiveness, and on the basis that school stand-downs contravene children and young people's human rights. This paper goes on to make suggestions for more positive and appropriate responses to inappropriate behaviour as well as advice for policy makers.

\section{Stand-downs in New Zealand Schools}

The decision to stand-down a student is at the discretion of the principal, and unlike a suspension or exclusion, does not require consultation with the Board of Trustees ${ }^{1}$ (Ministry of Education, 2009 ). The legal framework for the use of stand-downs in New Zealand schools is the 1989 Education Act (Sections 13-18) and the Education (Stand-down, Suspension, Exclusion and Expulsion) Rules (Education [StandDown, Suspension, Exclusion and Expulsion] Rules, 1999).

In 2013, there were 15,509 stand-down cases in New Zealand schools, received by 11,934 students. Of these, 69.1 percent took place in secondary schools with only 5.9 percent of secondary schools not using stand-downs. In comparison, 58.6 percent of primary schools did not use stand-downs. Since 2000, data has shown that schools are standing down Māori students more than any other ethnic group. In 2013, the stand-down rate for Mãori was 39.1 stand-downs per 1000. This figure is 1.5 times higher than the stand-down rate of Pasifika students who were stood down at a rate of 26.7 per 1000; and 2.4 times as high as the stand-down rate for European/Pakeha which was 16.3 per 1000 . The lowest stand-down rate by ethnic group were Asian students, at a rate of 6.5 per 1000 in 2011. Male students consistently experience more stand-downs than female students. The 2013 data show that males were stood down at a rate 2.7 times higher than the female rate. Students as young as six were stood down in 2013, though students aged 13 to 15 were most likely to be stood down, accounting for 59.2 percent of all stand-downs (Education Counts, 2014). In examining data since 2000, the stand-down rate in New Zealand peaked in 2006 at 30 stand-downs per 1000 students, and has followed a downward trend since, now at a rate of 21.6 stand-downs per 1000 students in 2013.

\footnotetext{
1 All of New Zealand's state and state-integrated schools have a Board of Trustees, elected by the parent community and staff members, responsible for the governance and management of the school.
} 
When examining the type of behaviour that leads to stand-downs, physical assault on other students was the main reason for stand-downs in 2013 comprising 26 percent of all stand-downs. Continual disobedience accounted for 22.8 percent of reasons for stand-downs, and verbal assault on staff had an occurrence of 12.9 percent in the stand-down data. These three behaviours accounted for close to twothirds of all stand-downs.

\section{Impact and Effect of Stand-Downs}

Research has shown that time spent out of class as a result of behavioural issues may exacerbate academic difficulties (American Academy of Pediatrics, 2003; Hemphill \& Hargreaves, 2009) and alienate at-risk students who most-likely need the supports a school can offer (American Academy of Pediatrics, 2003; Collin, 2001; Dharan, Meyer \& Mincher, 2012; Hemphill \& Hargreaves, 2009), and rather than improve student behaviour, stand-downs appear to predict future rates of misbehaviour and lead to further school stand-downs (American Psychological Association Zero Tolerance Task Force, 2008).

When managing difficult behaviour, schools face competing demands. There is a primary need to ensure a safe learning environment for all learners, however the needs and potential consequences of the stand-down on the individual student exhibiting behavioural difficulties also warrants consideration (Hemphill \& Hargreaves, 2009). Stand-downs are often used by schools to send a message to the school community about what is acceptable behaviour (Hemphill \& Hargreaves, 2009), however, internationally, researchers have been pushing to ensure that stand-downs are a last resort and that actions are taken within schools to ensure that standdowns are not used as a form of discipline (e.g. British Columbia Ministry of Education, 1999; Chin, Dowdy, Jimerson \& Rime, 2012; Collin, 2001; Fenning et al., 2012; Hemphill \& Hargreaves, 2009; Losen \& Gillespie, 2012; Michail, 2012; Smith, Bicard, Bicard \& Casey, 2012).

It appears that those students who arguably mostneed the support of teachers and peers are the ones most-likely to experience school stand-down (Blomberg, 2003; Hemphill \& Hargreaves, 2009) with numerous studies showing that these are often students who are already exhibiting signs that they are not managing at school (e.g. American Academy of Pediatrics, 2003; Collin, 2001; Dharan, Meyer \& Mincher, 2012; Hemphill \& Hargreaves, 2009). In particular, those students experiencing academic difficulties are particularly at-risk of adverse effects of school stand-down. Removing students from the learning environment results in a reduction in instruction time and may increase the academic difficulties that these students already experience (American Academy of Pediatrics, 2003; Chin et al., 2012; Hemphill \& Hargreaves, 2009).

As well as negative effects on academic outcomes, research has also shown that students who have been stood-down are more likely to drop out of school (Fenning et al., 2012; Hemphill \& Hargreaves, 2009; Losen \& Gillespie, 2012), engage in criminal acts and substance abuse (American Academy of Pediatrics, 2003; Hemphill \& Hargreaves, 2009), and are at a greater risk of incarceration (Losen \& Gillespie, 2012) and engaging in dangerous and harmful activities (Becroft, 2009).

The use of school stand-down as a tool to reduce undesirable behaviour, or to promote positive behaviour, lacks credible support in the literature. For example, a study from British Columbia, Canada, reported that discipline processes which served as punishment without instructional components have not been shown to decrease inappropriate behaviours (British Columbia Ministry of Education, 1999). On the contrary, rather than reducing the likelihood of future behavioural incidences, school stand-downs appear to predict further incidences of misbehaviour and stand-downs (American Psychological Association Zero Tolerance Task Force, 2008; Hemphill \& Hargreaves, 2009).

It has also been argued that using stand-downs as a response to challenging behaviours fits within a zero-tolerance approach to challenging behaviour (Advancement Project, 2010; American Psychological Association Zero Tolerance Task Force, 2008;

Browne-Dianis, 2011; Efreom-Lieber \& Lieber, 2010; Hemphill \& Hargreaves, 2009; Martinez, 2009).

Zero-tolerance policies can be defined as "rules with no leeway, such that certain behavioural acts lead to the automatic use of discipline strategies" (EfreomLieber \& Lieber, 2010, p. 105). This approach aims to reduce challenging behaviours through deterrence, by sending a message to the school community that certain behaviours will not be tolerated (Hemphill \& Hargreaves, 2009).

This zero-tolerance stance operates on the assumption that removing students who engage in inappropriate behaviours will allow others to continue learning in a safer environment (Advancement Project, 2010) and that the certain punishments of zero-tolerance would have a deterrent effect on students (American Psychological Association Zero Tolerance Task Force, 2008), thus improving both student behaviour and school discipline. The concern researchers raise with the zero-tolerance approach is that it is a one-size- 
fits-all approach to addressing discipline problems in school.

Interviews with both students who have been removed from school as a result of a disciplinary process and mainstream students who have not been involved in a stand-down consider the stand-down process ineffective or even counterproductive (Centre for Social Justice, 2011; McCluskey, 2008; Knipe, Reynolds \& Milner, 2007; Michail, 2012). Students report that often the time spent away from school is seen as a holiday and often students enjoy the time they spend away from school. McCluskey (2008) interviewed mainstream students about exclusionary practices at school, and reported that students perceived that teachers may consider a stand-down to work towards changing students' behaviour, but the students in the study reported feeling that stood-down students were being punished but not helped. The students interviewed felt that stand-downs were over-used, at times inappropriately used, and perceived a lack of consistency and effectiveness with the practice.

A report compiled by the Centre for Social Justice (2011) in the United Kingdom, reported student voices on stand-downs which included: "Most kids like it"; "I slept all day until my mates got home"; "I played X-Box"; "I got bored and angry"; "Everything kicked off at home because I was around too much" (p. 135), highlighting the importance of addressing student's behaviour rather than simply punishing them. Michail (2012) collected similar student reports in Australia, including "I reckon it's just a little holiday, you just get to have some fun at home. They reckon you're going to think about what happened at school but it just doesn't happen" (p. 8).

The importance of early identification of at-risk students, provision of individual support, a focus on developing positive attitudes and social skills as well as working in partnership with parents and family have been highlighted as fundamental areas to consider when attempting to reduce students' time outside of the class as result of behavioural difficulties (HM Inspectorate of Education, 2001). Through School-Wide Positive Behaviour (SWPB4L), the Ministry of Education has recognised that punitive and exclusionary approaches to discipline do not bring about long-term and sustainable changes in behaviour (Ministry of Education, 2013b) and promote the philosophy of teaching rather than punishing when faced with disciplinary and behavioural difficulties.

School-wide initiatives have shown to have a positive influence on stand-down rates (Horner et al., 2004; Ministry of Education, 2013a \& b). Schools working within positive behaviour support frameworks such as School-Wide Positive Behaviour for Learning (SWPB4L) in New Zealand report that when a shift from punitive to positive responses to student behaviour is made and the social climate of a school is shifted, stand-downs and suspensions are reduced (Bradshaw, Mitchell \& Leaf, 2010; Skiba \& Sprague, 2008). More specifically, Bradshaw et al., (2010) conducted a longitudinal study in Maryland, USA, of 37 schools over five years and reported that schools trained in school-wide positive behaviour showed a significant reduction in school stand-downs while schools that did not adopt the positive discipline philosophy showed no change in their stand-down rates over time.

Within New Zealand, the Ministry of Education's PB4L School-Wide Indicator Report (Ministry of Education, 2013c) reports that both achievement rates in PB4L: School-Wide schools have "improved significantly" (p. 25) as have retention rates of students remaining at school until 17 years and over, and there has been a "significant decrease in stand-down rates" (p. 25) over the first two years of implementation compared to schools not implementing the framework. Research tracking the progress of PB4L: School-Wide schools between 2009 and 2011 observed an average decrease in stand-downs of 17 percent (Ministry of Education, 2013c).

\section{A New Zealand Case Study}

The next section of this paper describes a small case study of two secondary school students who had been stood-down as a result of behavioural issues (White, 2013). Both students attended a Decile 5 co-educational secondary school in a provincial city with a student population of approximately 800 . The participants included two 15 Year-old year 11 students, one male (Tyson ${ }^{2}$ ) and one female (Destiny), who had recently been stood-down. The students involved in the study had been exhibiting on-going behavioural challenges and were selected by the principal and deputy principal at the study school for inclusion in the project as they had recently been stood-down. A family member of each student was also included in the study, as well as the principal and Year 11 dean. School behavioural data collected for each of the students was also provided by the school.

A successful application to a university Human Ethics Committee was made which ensured that all ethical principles were considered and appropriately addressed. In order to access participants for this research, the deputy principal of the school made initial contact with the students, and briefly explained

2 Both names are pseudonyms 
the research project to them. Both students consented to meeting with the researcher. When the researcher met with the students, a full explanation of the study was provided, and a consent form that had been approved by the university ethics committee was signed. The parents of both students were also contacted, and permission was sought and gained for their child's participation in the study.

Interviews with students, family members and school staff were conducted to gather the personal voice of those involved in a stand-down process and enabled the study to gather different perspectives on the standdown event and examine whether the risk factors cited in previous research were evident, as well as the perceived successfulness of the stand-down in changing difficult behaviour.

School interviews were conducted with both the principal and Year 11 dean of the study school. These interviews provided information on other supports that were put in place for the research students, both before and after the stand-down. The principal was also the homeroom teacher for one of the participants in the study, so his interview involved gathering perspectives of his role as leader of the school, and also as a support teacher for the student participant. In discussing his role as homeroom teacher, the principal was able to provide specific information on the participant's behaviour in his homeroom group through the school year including attendance, engagement and behaviour. The Year 11 dean was interviewed as he had been particularly involved with the female subject's disciplinary path throughout the school year.

In addition to interview data, the school provided the researcher with behavioural data from the school database. This included all recorded behavioural incidents for the 2013 school year. This allowed the researcher to examine school records of behaviour of concern, and show what led up to the decision by the school to stand these students down.

The study sought to address the question: In relation to two specific cases, what are the perspectives of the students, the students' parent(s) or caregiver(s) and school personnel regarding the present stand-down process and its effects?

\section{Data Analysis}

Interview data was collated and examined to highlight common themes, and also to provide a voice to all who were involved. The participant's interviews were transcribed and analysed for common themes. As all participants were interviewed using the same questions, the transcripts all had the same general construct, though levels of detail and additional information varied. A template was constructed to allow the information to be collated by interview subject so responses to each interview question could be compared to others reporting on the same event (see Table 1 for framework of interview questions).

\section{Table 1}

Interview Framework

\begin{tabular}{|l|}
\hline $\begin{array}{l}\text { Questions to Students, Family and } \\
\text { School Staff included: }\end{array}$ \\
\hline Participant background information \\
\hline Strengths of student \\
\hline Things student struggles with \\
\hline Previous trouble at school \\
\hline Types of behaviours exhibited \\
\hline Types of interventions prior to stand-down \\
\hline Details of event leading to stand-down \\
\hline Impact of stand-down on interviewee \\
\hline Impact of stand-down on student \\
\hline Did stand-down change student's behaviour? \\
\hline Suggestions on how to encourage student to change? \\
\hline Further details? \\
\hline
\end{tabular}

The analysis of the interviews also included examining if the circumstances surrounding these case study stand-downs reflected research which indicated that when stood-down, students are more-likely to engage in dangerous or anti-social behaviours. A list was made of behaviours described in the literature review, and cross-checked with the interviews. This was particularly relevant in the student interview transcripts, when perhaps school and family were unaware of what the students were doing during the stand-down.

\section{RESULTS}

\section{Different Perspectives of the Stand-Downs}

Destiny was referred by school senior staff as a suitable candidate for the study following a number of behavioural incidents. School behavioural records indicated that she had 13 recorded behavioural incidents in the 2013 school year to date. The descriptions of behaviour included absentee concerns (2 recorded incidences), continual disobedience 
(2), unacceptable behaviour (2), failure to follow instructions (1), truancy (1), deliberate defiance (1) and abuse of staff (1). Recorded school responses to these behaviours included phone calls and letters home, meetings with parents, a restorative chat, referral to the school counsellor and a two-day standdown. The stand-down was a response to her truancy and classified as 'continual disobedience'.

Destiny and her mother, who was at home with her during the stand-down, reported that she slept all day while at home from school. School felt that her stand-down was an opportunity for all parties to "take a breath" (Year 11 dean); while Destiny's mother felt that the stand-down was "bizarre" as Destiny was required to stay away from school following an incident of truancy. The dean acknowledged that he was not confident in the likelihood of a stand-down changing her behaviour, but felt that the school needed a way to show the student that the school was serious about wanting her behaviour to change.

Following her stand-down, the school removed Destiny from the classes in which she had the most behavioural difficulties, and she worked independently on high-interest subjects such as horticulture and geography in the office area. She established a good relationship with one of the teachers that used the office, and completed her independent work to fulfil the requirements to pass NCEA Level One, which the school reported exceeded expectations.

Tyson had 16 recorded behavioural incidents in the 2013 school year to the date of the research project. These incidents included uniform violations (8), unacceptable behaviour (1), absentee concern (1) and a stand-down for using synthetic marijuana. The consequences for his uniform violations were confiscation of the non-uniform clothing he was wearing, until, on his eighth violation, it was recorded that he was "defiant and arrogant", and his family was contacted.

While stood-down, Tyson reported that he spent time with his cousin who had also been stood-down for the marijuana incident and continued doing what he describes as "dumb stuff". They continued to smoke synthetic marijuana together, and once went to school to hang out in an area at the back of the school with their peers where students congregate to smoke. Upon their return to school following the stand-down, the boys were required to attend a meeting with the Board of Trustees, and Tyson reported that this began his journey to recovery. A number of the members of the Board of Trustees knew his family, and he said that the confrontation of his drug use "blew him away". He acknowledged the disappointment of his family, and told the Board that he was going to quit.

Tyson had been stood-down internally previously in 2013 for a behavioural incident in class. Three students in total were internally stood-down over this incident, and these students spent a day in separate interview rooms close to the office writing an apology letter to the teacher involved and completing work given to them by the learning-support teacher. Tyson reported that he did not feel that the internal stand-down changed his behaviour, but acknowledged that he was at school working for that day rather than having the freedom such as when he had time off school.

Both the school and Tyson's family member who was interviewed felt that his stand-down was effective in changing his behaviour. Tyson's family member reported that he stayed home and did chores whilst stood-down, but was left unsupervised when his caregiver was at work. In contrast, when he was asked if his stand-down changed his behaviour, Tyson replied "I'm not going to lie to you ... no. Honestly, the days that I got stood-down, we just went round to our mates and just kept going (smoking synthetic marijuana). Until that meeting we had - that gave me a shock".

Both case study students engaged in a number of perceived negative activities while stood-down. Tyson, reported to be unsupervised whilst stooddown, continued to use the drug that he was stooddown for, and went to school during his stand-down to spend time with his peers. Destiny reported that she primarily slept for the duration of her stand-down, but as her mother pointed out, she was stood-down for not attending school, which fulfilled the function of the behaviour. Previous research which highlighted factors that can be considered negative impacts of standing students down were compared to the study student's experiences, and summarised in Table 2. 
Table 2

Risk Analysis of Subjects' Stand-Downs

\begin{tabular}{|c|c|c|}
\hline Research Outcomes & Tyson & Destiny \\
\hline $\begin{array}{l}\text { Students unsupervised at home } \\
\text { (Meyer \& Evans, 2012) }\end{array}$ & Yes & No \\
\hline $\begin{array}{l}\text { Increase in home stress } \\
\text { (American Academy of Pediatrics, 2003; Meyer } \\
\text { \& Evans, 2012) }\end{array}$ & $\begin{array}{l}\text { Yes - family disappointed and } \\
\text { worried }\end{array}$ & $\begin{array}{l}\text { Yes - family meetings } \\
\text { difficult }\end{array}$ \\
\hline $\begin{array}{l}\text { Increased academic difficulties } \\
\text { (American Academy of Pediatrics, 2003; } \\
\text { Hemphill \& Hargreaves, 2009) }\end{array}$ & $\begin{array}{l}\text { Unable to ascertain within } \\
\text { study }\end{array}$ & $\begin{array}{l}\text { Unable to ascertain within } \\
\text { study }\end{array}$ \\
\hline $\begin{array}{l}\text { Anti-social behaviour rewarded } \\
\text { (Hemphill \& Hargreaves, 2009) }\end{array}$ & $\begin{array}{l}\text { Yes - time off school with } \\
\text { peers, engagement in } \\
\text { recreational drug use during } \\
\text { school time }\end{array}$ & $\begin{array}{l}\text { Yes - school-sanctioned time } \\
\text { off, did not have to truant }\end{array}$ \\
\hline $\begin{array}{l}\text { Engage in substance abuse while stood-down } \\
\text { (e.g. American Academy of Pediatrics, 2003; } \\
\text { Becroft, 2009; Hemphill \& Hargreaves, 2009) }\end{array}$ & Yes & Not reported \\
\hline $\begin{array}{l}\text { Engage in crime while stood-down } \\
\text { (e.g. American Academy of Pediatrics, 2003; } \\
\text { Becroft, 2009; Hemphill \& Hargreaves, 2009) }\end{array}$ & Yes - drug use & None reported \\
\hline $\begin{array}{l}\text { Further incidences of behavioural difficulties } \\
\text { following stand-down } \\
\text { (American Psychological Association Zero } \\
\text { Tolerance Task Force, 2008) }\end{array}$ & Yes - Continued lateness & $\begin{array}{l}\text { Yes - Continued attendance } \\
\text { difficulties }\end{array}$ \\
\hline $\begin{array}{l}\text { Encourage peers to truant with them } \\
\text { (Meyer \& Evans, 2012) }\end{array}$ & $\begin{array}{l}\text { Yes - went to school during } \\
\text { stand-down to try to get peers } \\
\text { to join him }\end{array}$ & Not reported \\
\hline $\begin{array}{l}\text { Engage in harmful activities while stood-down } \\
\text { (e.g. American Academy of Pediatrics, 2003; } \\
\text { Becroft, 2009; Hemphill \& Hargreaves, 2009) }\end{array}$ & Yes - drug use & Not reported \\
\hline
\end{tabular}

\section{DISCUSSION}

In relation to two specific cases, what are the perspectives of the students, the students' parent or caregiver, and school personnel regarding the present stand-down process?

Stand-downs are often used by schools to provide temporary relief following a behavioural incident (British Columbia Ministry of Education, 1999; Chin et al., 2012; Hemphill \& Hargreaves, 2009; Ministry of Education, 2009). However, research suggests that by sending students away from the routines and supervision that school provides they are providing students, who have shown to have difficulty managing their behaviour, time-off from academic instruction and too much freedom to engage in potentially dangerous acts (e.g. American Academy of Pediatrics, 2003; Becroft, 2009; Hemphill \& Hargreaves, 2009). In fact, some researchers argue that, rather than improving student behaviour, stand- downs actually function as a reward (Hemphill \& Hargreaves, 2009).

Both previous research and present findings do not indicate subsequent behavioural changes as a result of keeping students away from school due to behavioural difficulties. However, research does provide evidence that students engage in at-risk behaviour during stand-down periods. This present study supports research which suggests that keeping students away from school can function as a reward rather than punishment or catalyst for behavioural change. Previous studies have suggested that students are likely to engage in substance abuse, crime and other harmful activities whilst away from school (e.g. American Academy of Pediatrics, 2003; Becroft, 2009; Hemphill \& Hargreaves, 2009). In the present study, Tyson was stood down for using synthetic cannabis during school hours. While away from school, he continued this drug use, and spent time with the other students who were stood down for the 
same offence. Supporting research that students often encourage others to be truant with them (Meyer \& Evans, 2012), Tyson and his friends went to school during their stand-down, which would likely be perceived by students as flaunting that they were away from school and recreating as a result of a behavioural transgression.

Studies on student's perspectives show that students view stand-downs to be ineffective and counter-productive (Centre for Social Justice, 2011; McCluskey, 2008; Knipe, Reynolds \& Milner, 2007; Michail, 2012). The present study supports these views with comments made by both the students in the study: Destiny reported that her stand-down was just days off school, something she had sought through her truancy, while Tyson confirmed that while he was off school he was unsupervised and continued his drug use. In both cases the students clearly stated that the days off were not a punishment or a catalyst for change. In fact, their stand-downs did not reflect any negative feelings, and were likely reinforcing the negative behaviours that led to their time off school (Hemphill \& Hargreaves, 2009).

From the school's perspective, the homeroom teacher/principal reported that Tyson's stand-down was effective in changing behaviour. However, Tyson reported that it was not the stand-down that was a catalyst for behavioural change, but the re-integration meeting upon his return to school following his standdown that did impact on his behaviour. In the case of Destiny, an alternative to mainstream classroom learning was preferable to both her and the school staff. The successful intervention developed by the school involved her working independently on work units outside the classroom environment. Having her out of the classroom reduced pressure on her teachers, her classmates and herself, and without the distractions that the classroom environment provided, she was able to achieve academic success.

As well as social and academic arguments against the use of stand-downs there are also human rights arguments. The United Nations Convention on the Rights of the Child (United Nations General Assembly, 1989) which is legally binding to all members states (of which New Zealand is one such state) guarantees children ${ }^{3}$ specific human rights; in particular, their right to education (Article 28) and their right to have their best interests as the primary consideration in all actions and decisions concerning them (Article 3). Excluding children from schools denies them their right to access education, and research clearly shows that excluding children from school is not in their best interests.

The body of research on stand-downs indicates that there are detrimental and far-reaching negative consequences when children are excluded from school. Therefore, it appears timely for those involved in education to consider alternative and more appropriate methods of responding to inappropriate behaviour. One of these alternatives is the fostering of environments that lead to behavioural change and responses that teach students alternate and more appropriate behaviour.

Adopting a school-wide framework such as SW-PB4L to support behaviour at school has provided evidence as one way schools can implement a shift from a more punitive approach to school disciplinary issues to a more positive school climate that accepts that individuals make mistakes and teaches behaviours that schools would like to see. School-Wide PB4L looks at student behaviour in a tiered approach that emphasises prevention (Sugai \& Horner, 2009). At each tier, schools put systems and practices in place that match the needs of their students. Tier 1 focuses on universal behavioural support systems across the whole school, while Tier 2 looks at more intensive interventions for students who are not responsive to primary tier interventions and require additional behavioural support. This generally includes 0-15 percent of the student population. Tier 3 looks at supporting the 0-5 percent of students who exhibit chronic, challenging and severe behaviour with individualised and intensive behavioural supports (MOE, 2012b; Sugai \& Horner, 2009). This tiered system can be summarised by considering Tier 1 is for all students, Tier 2 is for some students, and Tier 3 is for a few students (MOE, 2013c).

The Ministry of Education expects it to take three to five years for a school to put the framework into place, but with the development of consistent expectations and models, research has indicated that schools report improved social climate and improved academic performance when following the school-wide programme (Horner et al., 2004; Skiba \& Sprague, 2008). Researchers have also shown that schools with school-wide behaviour plans are perceived as safer environments, suggesting that systematic implementation at the whole-school level is a useful practice (Spaulding et al., 2010). In New Zealand, research shows that behaviour has improved for schools who have introduced schoolwide behaviour plans which have included a schoolwide 'buy-in' with the following characteristics: creation of clear expectations through discussions about what is appropriate behaviour, establishment

3 Children are defined as those under the age of 18 
of consistent, immediate and fair consequences for both appropriate and inappropriate behaviour, and providing support for students to develop (Ministry of Education, 2013c). When looking at the success of SW-PB4L in reducing school stand-downs, it is important to highlight that it is not simply the process of adopting this framework that leads to the reduction of stand-downs, but the shift in school climate. Schools that are working from a positive discipline perspective respond differently to discipline issues, and consider options to teach from a student's mistake rather than send the student home.

The use of restorative practices have also been shown to be a positive alternative to standing down students. When a school is dealing with behavioural issues, restorative practices are an option to manage the situation in a positive light that encompasses the principles of positive discipline. Following a disciplinary infraction at a school, the use of restorative practices would involve a discussion involving all affected by the action. This would typically involve a conversation with the wrong-doer(s), and those who were affected by the action. Restorative practices in school challenges the concept that punishment is the best form of deterrence and instead looks at misconduct as a violation of people and interpersonal relationships that need to be healed and restored following an incident (Thorsborne \& Vinegard, 2002). By using restorative practices, wrong-doers have an opportunity to right their wrong and make amends to the people who were affected by their actions (Corrigan, 2012; Drewery\& Kecskemeti, 2010; Myer \& Evans, 2012; Thorsborne \& Vinegard, 2002). By taking responsibility for their actions, wrong-doers are able to learn from their mistakes.

The research and philosophies promoted within this project support a proactive approach to behavioural difficulties in schools. Positive Behaviour 4 Learning, and Restorative Practices, are two such approaches. However, there are other targeted programmes shown to bring about positive outcomes for students who experience difficulties with behaviour, and in particular, strategies focusing on the individual and unique needs of each student. In the present study, it was not until the school provided individualised interventions based on the specific needs of each individual that the student's behaviour improved. The key for schools to examine is how reactions to inappropriate behaviour can be developed without keeping students away from school and potentially putting students at risk.

\section{REFERENCES}

Advancement Project (2010). Test, punish, and push out: How 'zero tolerance' and high-stakes testing funnel youth into the school-to-prison pipeline. Washington, DC: Advancement Project.

American Academy of Pediatrics (2003). Committee on school health: Out of school suspensions and expulsion. Pediatrics, 112:1206-1209.

American Psychological Association Zero Tolerance Task Force (2008). Are zero tolerance policies effective in the schools? An evidentiary review and recommendations. American Psychologist, 63(9), 852-862.

Becroft, A. (2009). What causes youth crime and what can we do about it? Retrieved from: http://www. justice.govt.nz/courts/youth/publications-and-media/ speeches/what-causes-youth-crime-and-what-canwe-do-about-it Retrieved 14/0913.

Blomberg, N. (2003). Effective discipline for misbehavior: In-school versus out-of-school suspension. Concept, 27(11), 11-30.

Bradshaw, C. P., Mitchell, M. M., \& Leaf, P. J. (2010). Examining the effects of school-wide positive behavioral interventions and supports on student outcomes: Results from a randomized controlled effectiveness trial in elementary schools. Journal of Positive Behavior Interventions, 12(3), 133-148.

Browne-Dianis, J. (2011). Stepping back from zerotolerance. Educational Leadership, 69(1), 24-28.

British Columbia Ministry of Education, Special Programs Branch (BC MOE). (1999). Focus on suspension as a resource for schools. Retrieved from: https://www.bced.gov.bc.ca/sco/resourcedocs/ suspension_resource.pdf

Centre for Social Justice (2011). No excuses: A review of educational exclusion. Westminster, UK: Author.

Chin, J. K., Dowdy, E., Jimerson, S. R., \& Rime, J. R. (2012). Alternatives to suspensions: Rationale and recommendations. Journal of School Violence, 11(2), 156-173.

Collin, G. (2001). Suspended: When will they ever learn? Childrenz Issues, 9(1), 17-22.

Corrigan, M. (2012). Restorative practices in NZ: The evidence base. Retrieved from: http://www.vln. school.nz/file/download/687787.

Dharan, V., Meyer, L., \& Mincher, N. (2012). At the receiving end: Are policies and practices working to keep students in high schools? New Zealand Annual Review of Education 2011-2012, 21,119-141. 
Drewery, W., \& Kecskemeti, M. (2010). Restorative practice and behaviour management in schools: Discipline meets care. Waikato Journal of Education, 15(3), 101-113.

Education Counts (2014). Stand-downs, suspensions, exclusions and expulsions for school. Ministry of Education data. Retrieved from http://www. educationcounts.govt.nz/ indicators/main/studentengagement-participation/Stand-downs-suspensionsexclusions-expulsions

Education (stand-down, suspension, exclusion and expulsion) Rules (1999). Retrieved from http://www. legislation.govt.nz/regulation/public/1999/0202/ latest/DLM2884 25.htl

Efreom-Lieber, Y., \& Lieber, P. (2010). An ethical critique of suspension and zero-tolerance policies. The Australian Educational and Developmental Psychologist, 27(2), 104-114.

Fenning, P. A., Pulaski, S., Gomez, M., Morello, M., Maciel, L., Maroney, E., Schmidt, A., Dahlvig, K., McArdle, L., Morello, T., Wilson, R., Horowitz, A., \& Maltese, R. (2012). Call to action: A critical need for designing alternatives to suspension and expulsion. Journal of School Violence, 11(2), 105-117.

Hemphill, S., \& Hargreaves, J. (2009). The impact of school suspensions: A student wellbeing issue. ACHPER Healthy Lifestyles Journal, 56(3), 5-11.

HM Inspectorate of Education (2001). Alternatives to School Exclusion. Scotland.

Horner, R., Todd, A., Lewis-Palmer, T., Irvin, L., Sugai, G., \& Boland, J. (2004). The school-wide evaluation tool (SET): A research instrument for assessing school-wide positive behaviour supports. Journal of Positive Behavior Interventions, 6, 3-12.

Knipe, D., Reynolds, M., \& Milner, S. (2007). Exclusions in schools in Northern Ireland: The pupils' voice. Research Papers in Education, 22(4), 407-424.

Losen, D. J., \& Gillespie, J. (2012). Opportunities suspended: The disparate impact of disciplinary exclusion from school. The Civil Rights Project. Retrieved from: http://civilrightsproject.ucla.edu/ resources/projects/center-for-civil-rights-remedies/ school-to-prison-folder/federal-reports/upcomingccrr-research

Martinez, S. (2009). A system gone berserk: How are zero-tolerance policies really affecting schools? Preventing School Failure, 53 (3), 153-157.

McCluskey, G. (2008). Exclusion from school: What can 'included' pupils tell us? British Educational Research Journal, 34(4), 447-466.
Michail, S. (2012). "... because suspension doesn't teach you anything" (sic). What students with challenging behaviours say about school suspension. Paper presented at the AARE APERA International Conference, Sydney Australia.

Ministry of Education (2009). Guidelines for principals and boards of trustees on stand-downs, suspensions, exclusions and expulsions. Wellington, NZ: Author.

Ministry of Education (2013a). About school-wide positive behaviour for learning. Retrieved from: http://www.minedu.govt.nz/NZEducation/ EducationPolicies/ SpecialEducation/ OurWorkProgramme/PositiveBehaviourForLearning/ About.aspx

Ministry of Education (2013b). TKI: Positive behaviour for learning. Wellington, NZ: Author.

Ministry of Education (2013c). Positive behaviour for learning (PB4L). School-wide indicator report. Wellington, NZ: Author.

Meyer, L., \& Evans, I. (2012). The school leader's guide to restorative school discipline. Corwin: Thousand Oaks.

Skiba, R., \& Sprague, J. (2008). Safety without suspensions. Educational Leadership, 66(1), 38-43.

Smith, C., Bicard, S. C., Bicard, D. F., \& Casey, L. (2012). Decreasing in-school suspensions with function-based interventions. Kappa Delta Pi Record, 48(4), 174-177.

Spaulding, S., Irvin, L., Horner, R., May, S., Emeldi, M., Tobin, T., \& Sugai, G. (2010). School wide socialbehavioural climate, student problem behaviours and related administrative decisions. Journal of Positive Behaviour Interventions, 12(2), 69-85.

Sugai, G., \& Horner, R.H. (2009). Responsiveness-tointervention and school-wide positive behaviour supports: Integration of multi-tiered system approaches. Exceptionality, 17(4), 223-237.

Thorsborne, M., \& Vinegrad, D. (2002) Restorative practices in schools: Rethinking behaviour management. Inyahead:.Bundaberg.

United Nations General Assembly (1989). Convention on the rights of the child, 20 November 1989, United Nations, Treaty Series, Vol. 1577, p. 3. Retrieved from http://www.refworld.org/ docid/3ae6b38fo.html

White, C. (2013). Reducing school stand-downs - Case study in one New Zealand secondary school. Unpublished Masters Thesis, Massey University, Palmerston North, New Zealand. 


\section{AUTHOR PROFILES}

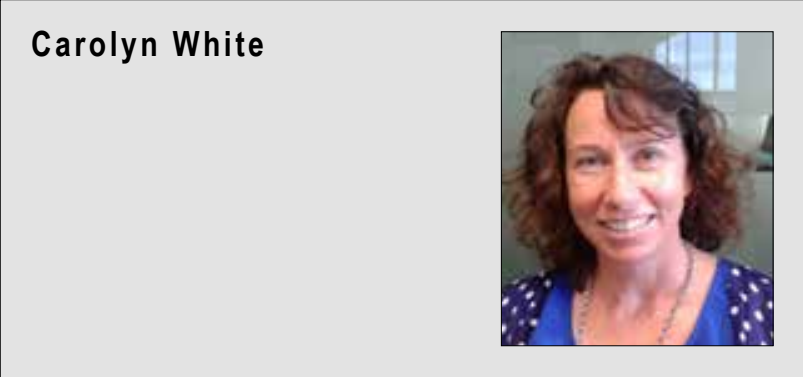

Carolyn White is a psychologist working for Special Education supporting students with behavioural difficulties. Prior to this she was a teacher in the primary school sector. Carolyn has a particular interest in reengaging excluded students back into education.

\section{Email:}

Carolyn.White@minedu.govt.nz

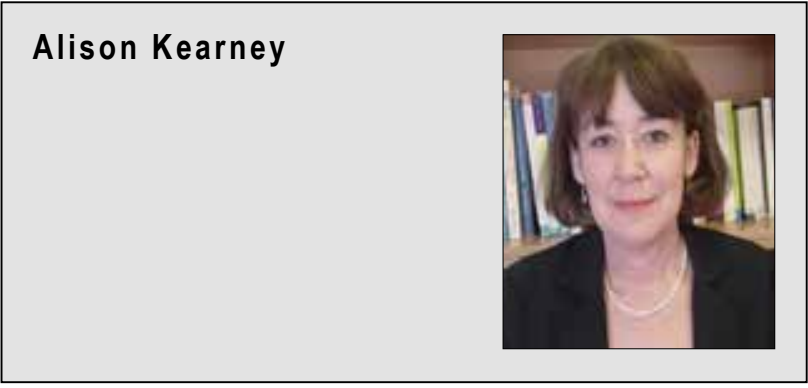

Alison Kearney is an associate professor at Massey University Institute of Education where she teaches and researches in the area of inclusive education. Prior to taking up her position at Massey University, Alison was a primary school teacher, a Resource Teacher of Special Needs, and a Guidance and Learning Teacher.

\section{Email:}

a.c.kearney@massey.ac.nz 